\title{
DID INTENSIVE FLOODS INFLUENCE HIGHER INCIDENCE RATE OF THE WEST NILE VIRUS IN THE POPULATION EXPOSED TO FLOODING IN THE REPUBLIC OF SRPSKA IN 2014?
}

\author{
Nina Rodić Vukmir ${ }^{1,2^{*}}$, Janja Bojanićn ${ }^{1,2}$, Biljana Mijovićs ${ }^{3,4}$, \\ Tatjana Roganovići ${ }^{2,5}$, Jela Aćimović1,2 \\ ${ }^{1}$ Institute of Public Health of the Republic of Srpska, Banja \\ Luka, Republic of Srpska, Bosnia and Herzegovina \\ ${ }^{2}$ Faculty of Medicine, University of Banja Luka, Banja Luka, \\ Republic of Srpska, Bosnia and Herzegovina \\ ${ }^{3}$ Regional Center Foča, Institute of Public Health of the Republic of Srpska, \\ Istočno Novo Sarajevo, Republic of Srpska, Bosnia and Herzegovina \\ ${ }^{4}$ Faculty of Medicine, University of Istočno Sarajevo, Foča, \\ Republic of Srpska, Bosnia and Herzegovina \\ ${ }^{5}$ University Clinical Center of the Republic of Srpska, \\ Banja Luka, Republic of Srpska, Bosnia and Herzegovina
}

\section{Abstract}

Climate change is definitely one of the greatest challenges of human development in the 21st century. Climate change is expected to increase the risk of communicable diseases in Europe. This impact will depend not only on local climatic conditions, but on other factors, such as current infrastructure, public health services, biodiversity specificity, etc. The population in Bosnia and Herzegovina, Croatia and Serbia has been severely affected by the floods caused by cyclone Tamara in 2014. The basic mode of transmission of the disease caused by the West Nile virus is the bite of the infected mosquito. The West Nile virus is not transmitted among humans through contact, nor can it be transmitted from infected birds to humans without mosquito bite. The aim of the study was to analyze and present the trend of this disease in the period 2014-2018 and to show the connection between the spatial occurrence of cases and location of the flooded area in 2014 in the Republic of Srpska. Using the descriptive method, the demographic data of the patients were analysed, the most common clinical form of the disease and the incidence of the disease in the period 2014-2018 was

${ }^{1 *}$ Corresponding author: nina.rodic@gmail.com 
analysed. The cases were mapped and we analysed the connection of the case and location that was flooded. The incidence ranged from 0.79 in 2014 to 0.43 in 2018. Patients were of all age groups and both sexes, most commonly cases from rural areas (78\%). The most common clinical form of the disease is shown, which were symptoms of the central nervous system infection. Out of the total number of patients, $94 \%$ were from flooded areas. All reported cases have been diagnosed at the Institute of Microbiology at the University Clinical Center of Republika Srpska and were reported as probable cases in accordance with the international case definition of communicable diseases. However, it is crucial to implement internationally endorsed procedures as a clinical alghoritm for the confirmation of the case in accordance with the laboratory criteria for the case definition. The occurrence, frequency and spatial distribution of cases indicates a possible connection with the floods in 2014.

Key words: West Nile Fever, Floods, Vector Diseases

\title{
DA LI SU INTENZIVNE POPLAVE UTICALE NE VEĆU INCIDENCU VIRUSA ZAPADNOG NILA U POPULACIJI IZLOŽENOJ POPLAVAMA U REPUBLICI SRPSKOJ U 2014 GODINI?
}

\author{
Nina Rodić Vukmir ${ }^{1,2}$, Janja Bojanić ${ }^{1,2}$, Biljana Mijović ${ }^{3,4}$, \\ Tatjana Roganović ${ }^{2,5}$, Jela Aćimović ${ }^{1,2}$ \\ ${ }^{1}$ Institut za javno zdravstvo Republike Srpske, Banja \\ Luka, Republika Srpska, Bosna i Hercegovina \\ 2. Medicinski fakultet Univerziteta u Banjaluci, Banja \\ Luka, Republika Srpska, Bosna i Hercegovina \\ ${ }^{3}$ Regionalni centar Foča, Institut za javno zdravstvo Republike Srpske, \\ Istočno Novo Sarajevo, Republika Srpska, Bosna i Hercegovina \\ ${ }^{4}$ Medicinski fakultet Univerziteta u Istočnom Sarajevu, \\ Foča, Republika Srpska, Bosna i Hercegovina \\ ${ }^{5}$ Univerzitetski klinički centar Republike Srpske, Banja \\ Luka, Republika Srpska, Bosna i Hercegovina
}

\section{Kratak sadržaj}

Klimatske promjene su definitivno jedan od najvećih izazova humanog razvoja u 21. vijeku. Očekuje se da će klimatske promjene povećati rizik 
od zaraznih bolesti u Evropi. Ovaj uticaj će zavisiti ne samo od lokalnih klimatskih uslova, nego i od drugih faktora, kao što su trenutna infrastruktura, usluge u sistemu javnog zdravlja, specifičnost biološke raznolikosti itd. Stanovništvo u Bosni i Hercegovini, Hrvatskoj i Srbiji je bilo teško pogođeno poplavama koje je izazvao ciklon Tamara 2014. godine. Osnovni način prenošenja bolesti Zapadnog Nila je širenje virusa ubodom zaraženog komarca. Virus Zapadnog Nila se ne prenosi među ljudima putem kontakta, niti se može prenijeti sa zaraženih ptica na ljude bez uboda komarca. Cilj studije je bio analizirati i prikazati kretanje ove bolesti u periodu 20142018. godina i prikazati moguću povezanost prostorne pojave slučajeva oboljenja sa poplavljenim područjem 2014. godine u Republici Srpskoj. Korišćenjem deskriptivnog metoda, analizirani su demografski podaci obolelih, a prikazana najčešća klinička forma bolesti i incidencija kretanja groznice zapadnog Nila u periodu 2014 - 2018. Slučajevi su mapirani i analizirana je povezanost lokacije slučaja sa područjem koje je bilo pogođeno poplavama. Incidencija se kretala od 0,79 u 2014. godini do 0,43 u 2018 . godini. Pacijenti su bili svih starosnih grupa i oba pola, a najčešće su to bili slučajevi sa ruralnih područja (78\%). Prikazana je i najčešća klinička forma obolelih, a to su simptomi infekcije i poremećaja centralnog nervnog sistema. Od ukupnog broja obolelih, njih $94 \%$ su sa poplavljenih područja. Svi prijavljeni slučajevi su dijagnostikovani u Zavodu za mikrobiologiju Univerzitetskog kliničkog centra Republike Srpske i vode se kao vjerovatni slučajevi u skladu sa međunarodnom definicijom slučajeva zaraznih bolesti. Međutim, ključno je sprovesti međunarodno usvojene procedure kao klinički algoritam za potvrdu slučaja u skladu sa laboratorijskim kriterijima za definiciju slučaja. Pojava, učestalost i prostorna raspodjela slučajeva ukazuje na moguću povezanost sa poplavama 2014.godine.

Ključne riječi: groznica zapadnog Nila, poplave, vektorske bolesti

\section{INTRODUCTION}

A recent study by the European Center for Disease Prevention and Control has found that vector-borne diseases are one of the eight major communicable threats for Europe, along with the emergence and spread of resistance to antibiotics or pandemic influenza (Semenza et al., 2018). Climate changes affect the survival and transmission of arthropod vectors, as well as the rates of development of pathogens that are transmitted by the vectors. There was a significant correlation between mean temperature, precipitation and mosquito density (Lee et al., 2013). This resulted in the seasonal epidemics of West 
Nile fever in the countries across the Europe for which there is no effective control measure such as vaccine in humans. Even the availability of an equine vaccine did not prove to be a solution because the coverage was low, probably due to sporadic epidemics and the relatively high cost of vaccine for the owners (Findlater et al., 2018). Ambient temperature is one of the most important abiotic factors affecting the life of the insect. Mosquitoes, such as Aedes aegypti and Aedes albopictus, transmit many pathogens, including Denge, Chikungunye and Zika viruses. The spread of these diseases has become the main global health issue and it is predicted that the climate change will affect the distribution of mosquitoes, which will enable these insects to introduce new pathogens into sensitive populations (Reinhold et al., 2018). Due to the combination of anthropogenic changes, including effects on the global climate and migration of wild animals, there is strong evidence that the regions with a moderate climate have repetitive occurrence of mosquito-borne diseases, but also the emergence of those diseases that have not previously been detected through surveillance.

In Europe, the re-emergence of West Nile virus (WNV) and Usutu virus is associated with the bird migration from Africa, while the autochthonous transmission of Chikungunya and Denga viruses is fuelled by a combination of invasive mosquitoes and rapid transcontinental travel by infected people (Johnson et al., 2018). Arboviruses are a diverse group of viruses that are transmitted by the vectors, many of which cause significant human morbidity and mortality. Continuous geographical expansion of the Dengue virus, along with explosive epidemics of the WNV, Chikungunya and Zika, served as a reminder that a new epidemics can occur at any time from this diversity. A clearer understanding of the mechanisms that trigger these dramatic changes in the transfer cycles from host to host that result in a significant exposure of the human population will help us prepare for the next epidemic/pandemic (Young, 2018). Arboviruses such as WNV, Zika, Chikungunya, Dengue and Yellow fever have become very significant global pathogens through unexpected, explosive epidemics (Rückert et al., 2018).

A constant occurrence is evident during summer months in Europe (from July to September) when higher ambient temperatures favor the activity of mosquitoes, while winter months (December to February) generally lead to cessation of their activity. Environmental studies in southern and northern Europe illustrate this, showing the highest number of species in the summer months. It is during these peaks of the season that the autochthonous transmission of the virus takes place and the occurrence of diseases caused by mosquitoes is observed. The autochthonous transmission of viruses in mosquitoes 
in Europe is dominated by the emergence of the number of exotic viruses. The best example of this is the re-occurrence of WNV, which is mainly transmitted by the mosquito species of the genus Culex. The epidemiology of the WNV is complex, and it consists of a cycle of infection between mosquito species that serves as a vector of the virus, wild birds acting as a reservoir and illness in humans and horses. The whole cycle must include populations of mosquitoes that bite birds and mammals. Examples of these populations include the Culex pipiens population (Vogels et al., 2016), especially those in southern Europe, as well as Culex modestus (Balenghien et al, 2008). Models that predict the time and location of human infection with Arboviruses have the potential to more effectively control mosquitoes and prevent disease. The objectives of this study were to analyze and present the occurrence and trend of the West Nile fever in the period 2014-2018, to analyze cases according to the place of residence and determine whether there was a higher incidence of the disease in the flooded area in 2014 as compared with the other parts of the Republic of Srpska, and to present a WNV case classification of patients based on the diagnostic method and the case definition criteria.

\section{MATERIAL AND METHODS}

Using the descriptive method, the demographic data of the patients were analyzed, and the classification of cases based on case definition were performed. The most common clinical forms of the disease and the incidence of the West Nile fever in the period 2014-2018 in the Republic of Srpska were described. All cases reported in the Republic of Srpska were mapped and we analyzed the correlation of the location of the case with the area affected by the floods. Also, each case has been monitored in terms of clinical course of the disease and the outcome of the treatment. Each case has been reported in accordance with the adopted case definition for West Nile fever of the European Center for Disease Control, which is obligatory to be applied in accordance with the current Regulations on the manner of reporting, the contents of records and the content of the notification of infectious diseases (Official Gazette of the Republic of Srpska 07/19). The case can be classified as possible - probable - confirmed on the basis of the case definition criteria.

- Clinical criteria: any person with a high fever or at least one of the following two criteria: encephalitis, meningitis.

- Laboratory criteria: A laboratory test for case confirmation implies at least one of the following four criteria:

- Isolation of WNV from blood or liquor, 
- Detection of WNV nucleic acid in the blood or liquor,

- Detection of IgM antibodies specific to WNV in the liquor

- High titre of IgM antibody on WNV and detection of IgG antibody on WNV, and confirmation by neutralization

A laboratory test for a probable case is the antigenic specific response to WNV in serum.

- Epidemiological criteria: at least one of the following two epidemiological links:

- Transfer from animal to human (permanent or shorter stay or exposure to mosquitoes in areas where WNV is endemic in horses or birds),

- Transfer from person to person (vertical transmission, blood transfusion, transplants).

After clinical and epidemiological criteria were confirmed, a sample of blood was taken from each patient and tested for the presence of IgM and IgG antibodies using ELISA according to the manufacturer's instructions (Euroimmun, Germany) at the Institute of Clinical Microbiology at the University Clinical Center of Republika Srpska (UCC RS). Each patient has been monitored in terms of clinical course and outcome.

\section{RESULTS}

In the period 2014-2018, a total of 18 cases of West Nile fever were reported. The incidence ranged from 0.79 in 2014 to 0.43 in 2018, which clearly corresponds with large floods that affected the Republika Srpska in 2014 (Figure 1). Based on a descriptive analysis, the data showed that the average age of patients in the observed period was 51.7 years. The youngest patient was 6 and the oldest one was 87 years old, but there was no statistically significant difference in the number of patients between different age groups. The results of the $\chi^{\wedge} 2$ test $\left(\chi^{\wedge} 2=3.556 ; p=0.096\right)$ showed that there was no statistically significant difference $(\mathrm{p}<0.05)$ in the number between male and female patients. Based on the statistical analysis, it was concluded that there was a statistically significant difference in the number of patients by the type of settlement in which they lived. Statistically significant $(p=0.018<0.05)$ was the higher number of patients living in the rural area as compared to the number of patients living in the urban area, exactly $76 \%$ of them. 


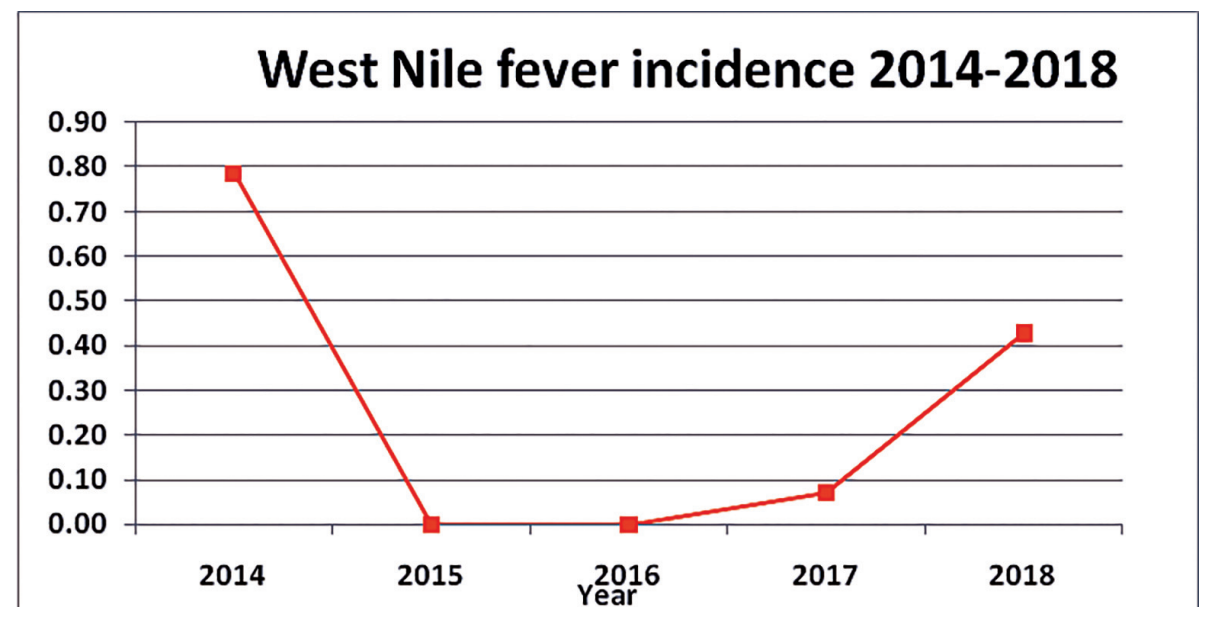

Figure 1. Incidence of the WNF 2014 - 2018 in the Republic of Srpska

The results of $\chi^{\wedge} 2$ test $\left(\chi^{\wedge} 2=14,222 ; \mathrm{p}=0,000\right)$ revealed a statistically significant difference in the number of patients according to whether they lived in a settlement that was flooded or not. Significantly higher number of patients lived in settlements that were flooded as compared to the number of patients living in settlements that were not affected by the floods (Figure 2).

\section{Is the WNF case from the flooded area?}

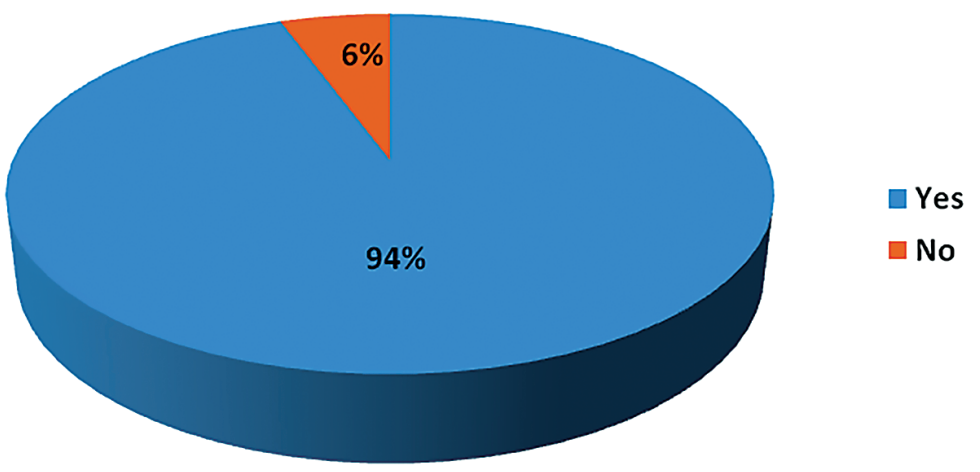

Figure 2. Representation of the West Nile fever cases in the flooded area in the Republic of Srpska 
Of the total number of patients, $94 \%$ were from the flooded areas belonging to the municipalities of Šamac, Derventa, Modriča, Prijedor, Novi Grad, Banja Luka, Teslić, Petrovo, which corresponds exactly to the map of the areas that were affected by catastrophic floods in 2014 (Figure 3). Out of all cases, $90.9 \%$ were reported in June and July 2014, that is, less than a month or two after the flood. The most common clinical form of the disease was neuroinvasive infection with a fever and meningoencephalitis (100\%), which fully meets the criteria of the case definition of this disease. All reported cases have been tested at the Department of Microbiology (UCC RS) with a positive finding of serum IgM and IgG antibodies and are reported as probable cases in accordance with the international case definition of this infectious disease. All patients were dissmised completely recovered.

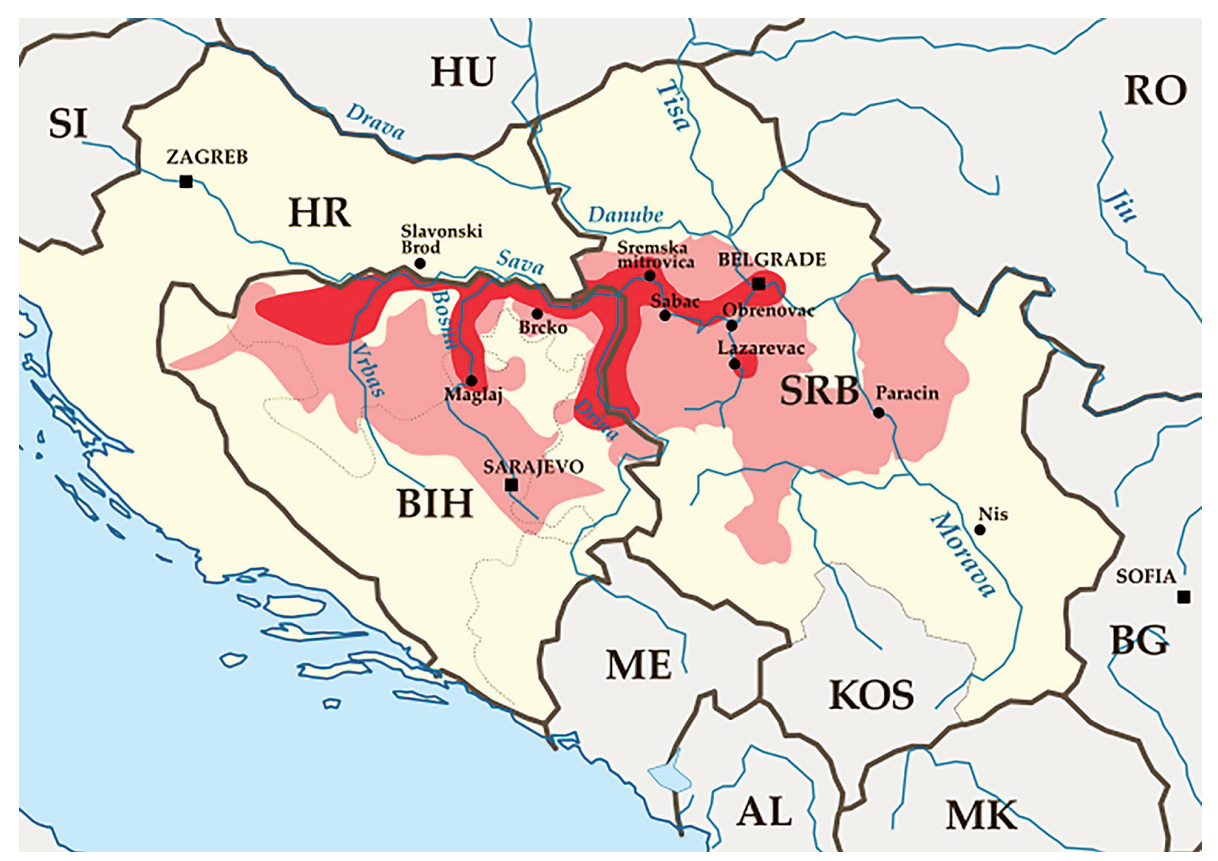

Figure 3. Map of the flooded region in 2014 (Source: Arnold Platon based on European Comission press releases for 16 May and 20 May, ECHO/AFP map, The Guardian map and Al-Jazeera Balkans interactive map,

\section{DISCUSSION}

Since its discovery in 1937, WNV has spread beyond its original geographical area and has caused disease on all continents except in Antarctica. The 
main goal of the West Nile fever control in the human population is to continuously monitor the epidemiological, clinical and virological characteristics of the WNV in order to take appropriate measures to prevent and control the spread of the disease. Reported cases of illness and/or deaths from the West Nile fever neuroinvasive form in the human population are the most accurate indicators of the activity of the WNV in humans. It is necessary to evaluate potential risk factors for infection and possible transmission within a period of three weeks before the onset of symptoms of the disease. The case of West Nile fever should be suspected in people over 50 years of age presenting with encephalitis or meningitis in the summer or early autumn months. Restricting the blood donation should be considered in areas where this virus is circulating. There are specific rules in the EU that address the safety of blood by delaying voluntary donations of 28 days after leaving the area in which there is a transmission (EU Commission Directive 2004). The epidemiological situation of the disease in Europe is heterogeneous: some countries report epidemics in humans and animals every year, while others have never reported any autochthonous cases. The concept of "One Health" recognizes that the health of people, animals and the environment is interconnected and that only a collaborative interdisciplinary approach can effectively achieve optimal health outcomes (Lerner et al., 2015).

After the catastrophic floods that affected the Republic of Srpska in 2014, on May 26, 2014, a Webex conference was held with the representatives of Bosnia and Herzegovina, Croatia and Serbia, the World Health Organization and the European Center for Disease Control. The aim of the meeting was to discuss on necessary measures to prevent the outbreak of diseases that are transmitted to the vectors. The main risk identified as a threat to human health is the epidemic of the WNV.

The first case of West Nile fever has been reported to the Institute of Public Health of the Republic of Srpska on 10 June, 2014. This first-reported case was from the Banja Luka area, followed by cases from the municipalities of Novi Grad, Teslić, Derventa, etc. All patients were hospitalized on the basis of relevant clinical symptoms and some were later transferred to further diagnostics and treatment to the University Clinical Center of the Republic of Srpska in Banja Luka. Since all sera of the patients were tested positive for IgM and IgG antibodies using the ELISA, they were all classified as a probable cases. However, University Clinical Center of the Republic of Srpska doesn't sample cerebrospinal fluid for confirmation of the cases, which is a weak spot in the management of the cases and surveillance of the disease. Therefore, this procedure should be implemented in the future according to the European Center 
for Disease Control case definition for confirmation (Hrnjakovic Cvjetkovic et al., 2018). This is very important for distinguishing WNV from tick-borne encephalitis and other arboviral infections as they have very similar clinical manifestations (Petrovic et al., 2018). It is important to emphasize that this is a passive surveillance and there were no intensive measures to detect cases using different procedures than usually. The increase of incidence was not the consequence of active surveillance and tracing of the cases. One of the factors that might have influenced such condition was the fact that the population from the flooded area spent more time outside, repairing the damage after the floods and working around artificial water ponds.

That same year 2014, Italy reported the epidemic of West Nile fever in human and equine population caused by the WNV of lineage 1 (Delbue et al., 2014). WNV lineage 2 is responsible for the outbreak of the epidemic in the same year in Hungary and Greece (Hernandez-Triana et al., 2014). This trend of outbreaks continued in the summer and early autumn months throughout the region. In Austria, 2 cases were registered (Kolodziejek et al., 2014) and the reporting continued in 2015 with 8 new cases. In 2018, 2083 cases were reported in Europe. EU member states reported 1503 cases, which is more than 7-fold increase compared to 2017, mostly in Bulgaria, France and Italy. The neighboring countries of the European Union reported 580 human cases, out of which 415 cases were registered in Serbia (ECDC, 2018).

Monitoring of the disease in humans focuses on early detection of cases and identification of affected areas aimed at the implementation of relevant measures including safety standards for blood transfusion, vector control and communication with relevant institutions and the public. This is particularly challenging because most cases are asymptomatic, which is a particular risk in aspects of blood and organs donations.

The integration of surveillance and surveillance activities carried out by the public health authorities, animal health care institutions and institutions responsible for vector control and surveillace should enhance efficiency and save resources by targeted measures (Gossner et al., 2017).

\section{CONCLUSION}

In the period 2014-2018, the highest incidence of West Nile fever was recorded in 2014 when the Republic of Srpska was affected by the floods. All hospitalized and analysed patients had neuroinvasive disease. Most cases were registered in flooded areas mainly among rural populations. It is necessary to perform more analyses in close cooperation with the veterinary sector to 
establish and confirm the interconnection between disease cases, floods and infected mosquitoes in the flooded area. All cases are classified as "probable cases"; however, it is crucial to implement internationally endorsed procedures as a clinical alghoritm for the confirmation of the case in accordance with the laboratory criteria for WNV case definition.

\section{REFERENCES}

1. Balenghien T, Vazeille M, Grandadam M, Schaffner F, Zeller H, Reiter P, Sabatier P, Fouque F, Bicout D. 2008.Vector competence of some French Culex and Aedes mosquitoes for West Nile virus. Vector Borne Zoonotic Dis. 8, 589-595;

2. Commission Directive 2004/33/EC of 22 March 2004 implementing Directive 2002/98/EC of the European Parliament and of the Council as regards certain technical requirements for blood and blood components;

3. Delbue S, Ferrante P, Mariotto S, Zanusso G, Pavone A, Chinaglia M, L'Erario R, Monaco S, Ferrari S. 2014. Review of West Nile virus epidemiology in Italy and report of a case of West Nile virus encephalitis. J. Neurovirol. 20, 437-441;

4. ECDC: Epidemiological Update 14th December. Available online: https:// ecdc.europa.eu/en/news-events/epidemiological-update-west-nile-virustransmission-season-europe-2018;

5. Findlater A. and Bogoch I. 2018. Human mobility and the global spread of infectious diseases: A focus on air travel. Trends Parasitol. 34, 772-783;

6. Gossner CM, Marrama L, Carson M, Allerberger F., Calistri P., Dilaveris D., Lecollinet S., Morgan D., Nowotny N., Paty M., Pervanidou D., Rizzo C., Roberts H., Schmoll F., Van B.W., Gervelmeyer A. 2017. West Nile virus surveillance in Europe: moving towards an integrated animal-human-vector approach. Euro Surveill. 22(18):30526;

7. Hernández-Triana L, Jeffries C, Mansfield K, Carnell G, Fooks A, Johnson N. 2014. Emergence of West Nile virus lineage 2 in Europe: A review on the introduction and spread of a mosquito-borne disease. Front. Public Health 2, 271;

8. Hrnjakovic Cvjetkovic I., Milosevic V., Pettrovic T., Petric D., Kovacevic G., Radovanov J., Patic, A., Nikolic, N., Stefan Mikic, S., Cvjetkovic, S., Cvjetkovic, D. 2018. Diagnosis of West Nile neuroinvasive disease in humans. Arhiv veterinarske medicine, 11,1, 79 - 89;

9. Johnson N, Fernández de Marco M, Giovannini A, Ippoliti C, Danzetta ML, Svartz G, Erster O, Groschup MH, Ziegler U, Mirazimi A, Monteil V, Beck C, Gonzalez G, Lecollinet S, Attoui H, Moutailler S. 2018. Emerging 
Mosquito-Borne Threats and the Response from European and Eastern Mediterranean Countries. Int J Environ Res Public Health.;15(12). pii: E2775. doi: 10.3390/ijerph15122775;

10. Kolodziejek J., Seidel B., Jungbauer C., Dimmel K., Kolodziejek M., Rudolf I., Hubálek Z., Allerberger F., Nowotny N. 2015. West Nile virus positive blood donation and subsequent entomological investigation, Austria, 2014, PLoS One. 10(5):e0126381;

11. Lee S.H., Nam K.W., Jeong J.Y., Yoo S.J., Koh Y.S., Lee S., Heo S.T., Seong S.Y., Lee K.H. 2013. The effects of climate change and globalization on mosquito vectors: evidence from Jeju Island, South Korea on the potential for Asian tiger mosquito (Aedes albopictus) influxes and survival from Vietnam rather than Japan. PLoS One. 24;8(7):e68512. doi: 10.1371/journal.pone. 0068512;

12. Lerner H., Berg C. 2015. The concept of health in One Health and some practical implications for research and education: what is One Health? Infect Ecol Epidemiol. 2015;5:25300. doi:10.3402/iee.v5.25300;

13. Petrovic T., Sekler M., Petric D., Vidanovic D., Potkonjak A., Hrnjakovic Cvjetkovic I., Savic S., Debeljak Z., Lazic, G., Ignjatovic-Cupina A., Lupulovic D., Samojlovic M., Jurisic A., Petrovic A., Ivanovic I., Milosevic V., Lazic S. 2018. Flaviviruses at the territory of Serbia- present situation and challenges. Arhiv veterinarske medicine 11, 2, 53 - 70;

14. Reinhold J.M., Lazzari C.R., Lahondère C. 2018. Effects of the Environmental Temperature on Aedes aegypti and Aedes albopictus Mosquitoes: A Review. Insects. 6;9(4). pii: E158. doi: 10.3390/insects9040158;

15. Rückert C. and Ebel G.D. 2018. How Do Virus-Mosquito Interactions Lead to Viral Emergence? Trends Parasitol. 34(4):310-321. doi: 10.1016/j. pt.2017.12.004;

16. Semenza J.C. and Suk J.E. 2018. Vector-borne diseases and climate change: A European perspective. FEMS Microbiol. Lett. 365, fnx244;

17. Vogels C.B., Möhlemann T.W., Melsen D., Favia G., Wennergren U., Koenraadt C.J. 2016. Latitudinal diversity of Culex pipiens biotypes and hybrids in farm, peri-urban, and wetland habitats in Europe. PLoS ONE 11, e0166959;

18. Young P.R. 2018. Arboviruses: A Family on the Move. In: Dengue and Zika: Control and Antiviral Treatment Strategies. Advances in Experimental Medicine and Biology, Eds. Hilgenfeld R., Vasudevan S., vol 1062. Springer, Singapore.

Submitted: 02.04.2019.

Accepted: 05.06.2019. 